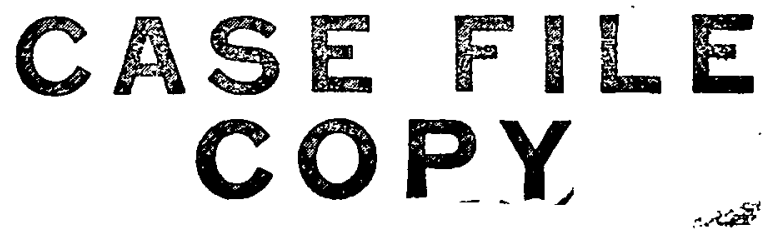

S.IMPLIFIED FABRICATION OF BACK SURFACE ELECTRIC FIELD SILICON CELLS AND NOVEL CHARACTERISTICS OF SUCH CELLS

by Joseph Mandelkorn and John H. Lamneck, Jr. Lewis Research Center

Cleveland, Ohio

TECHNICAL PAPER proposed for presentation at Ninth Photovoltaic Specialists Conference sponsored by the Institute of Electrical and Electronics Engineers Silver Spring, Maryland, May 2-4, 1972 


\title{
SIMPLIFIED FABRICATION OF BACK SURFACE ELECTRIC FIELD SILICON CELIS AND NOVEL CHARACTERISTICS OF SUCH CELIS
}

\author{
Joseph Mandelkorn and John H. Lemneck, Jr. \\ Lewis Research Center \\ National Aeronautics and Space Administration \\ Cleveland, Ohio
}

\section{SUMMARY}

An investigation of the characteristics and behavior of $10 \Omega-\mathrm{cm}$ silicon cells having abnormally high open-circuit voltages was made. The cells studied were made by a new, highly simplified, contact fabrication process which creates both a contact and a thin electric field region at the cell back surface without the need for phosphorus layer removal. These cells had opencircuit voltages of about $0.58 \mathrm{~V}$ and their performance as a function of thickmess, temperature, and $I \mathrm{MeV}$ electron irradiation is detalled. The study showed that $10 \Omega-\mathrm{cm}$ back-surface-field cells can have the high initial efficiencies and desirable temperature behavior of low resistivity cells. Thin back-surface-field cells were made and showed, in addition, much greater radiation damage resistance. A mechanism is proposed to explain the results.

\section{TNTRODUCTION}

A comprehensive theoretical treatment of field effects in silicon solar cells has been presented by Wolf ( 1 ). The theory predicts that increases in long wavelength response of cells are attainable by incorporation of electric field regions into the cell bulk. More recently, there have been reports of the achievement of unusually high open-circuit voltages and short-circuit currents in $10 \Omega-\mathrm{cm}$ cells $(2,3)$. These results were attributed to a gettering process which removes detrimental impurities from the cell bulk, increasing the minority carrier diffusion length to hitherto unattained values $(2,3)$. The gettering process was not disclosed.

Wolf extended his calculations (4) to show that the presence of a thin electric field region at a cell back surface could produce significant increases in long-wavelength response. However, the refined analys is made by Wolf did not show a relationship of such a field to cell open-circuit voltage.

Extensive experimental work at the Lewis Research Center has shown that the open-circuit voltage of $10 \Omega-\mathrm{cm}$ cells saturates at a maximum value of about $0.55 \mathrm{~V}$. It therefore was questionable that increase of minority carrier diffusion length by a gettering process resulted in the $0.585 \mathrm{~V}$ open-circuit voltages reported for $10 \Omega$-cm cells $(2,3)$. A study was made of the effects of back surface $\mathrm{p}^{+}-\mathrm{p}$ electric fields on cell behavior because it was surmised that such fields were most likely responsible for the high open-circuit voltages reported.

\section{EXPERIMENTAL PROCEDURES}

\section{Ce11 Fabrication}

Silicon solar cells were fabricated using a new back surface contacting process which hereafter will be referred to as the alloy-through process. Cell fabrication was carried out as shown in figure 1.

Phosphorus was diffused into " $p$ " type $1 \times 2$ $\mathrm{cm}$ silicon wafers at a temperature of $840^{\circ} \mathrm{C}$ for a time of one-half hour from a phosphorus oxychloride vapor source. Following diffusion, surface oxides on the wafers were removed by immersing them in a 0.5 percent hydrofluoric acid solution. The wafers were then inserted into metal masking jigs which were positioned in a vacuum system. Silver was evaporated over the top surface of the wafers in a ten grid-finger contact pattern (5) and several micrometers of aluminum were evaporated over the entire back surface of the wafers. After removal from the masking jigs, the wafers were inmediately heated in a furnace at $800^{\circ} \mathrm{C}$ for a time of four hours in an argon atmosphere. This heating cycle did not have any adverse effects on either the properties of the $\mathrm{Ag}$ front contact or on the $n^{+}-p$ junction below it. During the heating cycle, aluminum first alloys through the phosphorus diffused region on the wafer back surface forming a low resistance contact to the bulk. The alloyed region then serves as a source of aluminum which diffuses into the bulk to an estimated depth of approximately one micrometer during the four-hour $800^{\circ} \mathrm{C}$ heating cycle. It is thus possible to form a thin electric field region and a low resistance contact at the back of the cell and to simplify the contact fabrication process by use of the alloy-through process. Cell fabrication is completed by masking the top and bottom surfaces of the wafer with wax and etching to remove the phosphorus diffused region from the cell edges.

All cells made had a ten grid finger contact pattern (5) and an active area of $1.7 \mathrm{~cm}^{2}$. This value of active area is 3 percent less than that of commercial five grid finger cells. The series resistance of the cells, as measured by a twolevel illumination method (6), was 0.25 ohms. This compares with values of 0.5 ohms measured 
for $1 \times 2 \mathrm{~cm}$ commercial cells. Sheet resistances of all cells made were similar to those of commercial cells and ranged from 60 to 90 ohms/sq. , and cell short wavelength responses were similar to those measured for high quality commercial cells. Fill factors of field cells were above 75 percent, ranging up to 78 percent, well above fill factors of commercial cells.

To properly evaluate the behavior of the field cells, control cells (conventional $n^{+}-p$ geometry) were fabricated from the same region of the silicon ingots as the field cells and measurements were made sequentially on both cell types. Variations in control cell processing were made to obtain equivalent sheet resistances in both field and control cells and to ensure that the control cells had no field region at the back contact.

Table I compares the alloy-through process with a normal process used for forming a back surface field. Field cells made by either process were identical in their performance. The use of the alloy-through process permits elimination of steps 4,5 and 6 as shown.

A significant economic advantage consisting of savings in labor, materials, and facilities, and reduction of thin cell handling breakage is attainable by use of the alloy-through process. In addition, it becomes possible to evaporate contacts on wafer surfeces untouched by the masking materials and cleaning solvents used in steps 4,5 and 6 . Therefore, more reliable and adherent contacts may be realized as a result of alloythrough processing.

\section{Analysis and Discussion}

Table II compares the characteristics of $10 \Omega-\mathrm{cm}$ alloyed-through-and-diffused back surface field cells with those of control cells made from the same region of a silicon ingot but having non-alloyed back contacts. The efficiencies shown in the table are calculated by assuming an antireflection coating with a coating factor of 1.4 has been applied to all the cells; the fillfactor and open-circuit voltage values used were those shown in the table. The field cell characteristics are very similar to those of the unusual cells previously reported $(2,3)$. It should be noted that 0.004 -inch-thick field cells can have efficiencies equal to those of the thickest $10 \Omega-c m$ conventional structure cells.

Several experiments were performed to determine whether the high open-circuit voltages of alloyed-through field cells were due to the presence of the field at the cell back surface. In the simplest experiment, 0.002 inch of silicon was removed from the back surface of a $0.012-$ inchthick field cell by abrasion and was replaced by a rhodium contact (7) plated on at room temperature. The cell open-circuit voltage dropped from 0.573 to 0.537 volt, a normal value for a $10 \Omega-\mathrm{cm}$ 0.010-inch-thick cell. In another experiment, a $p^{+}-p$ field was created at the back surface of several cells by diffusion of boron into the back surface. Cells so made had the characteristics and behavior of the alloyed and diffused-aluminum field cells, proving that gettering by means of a molten alloy on the cell back surface was not required to achieve unusually high open-circuit voltages in $10 \Omega-\mathrm{cm}$ cells.

Cells were also made which had either of the two back surface contact configurations shown in figure 2. Cells having the Type 1 (window contact) back surface contact configuration depicted had low contact resistance and good diode characteristics. However, their open-circuit voltages were the same as for the control cells in Table II. This contrasted with the results for cells having the Type 2 (full coverage) contact configuration. These Type 2 back contact cells had the characteristics of back surface field cells as shown in Table II. Evidently the $\mathrm{n}^{+}$window frame surrounding the $\mathrm{p}^{+}-\mathrm{p}$ region in the Type 1 configuration acts as a shunt which destroys the effectiveness of the $p^{+}-p$ window region. Since the same alloying and heating steps were used with both contact geometries, it can be concluded that impurity gettering by the molten alloy was not responsible for the high voltages.

Further experiments elucidated the mechanism by which the back surface field increases the open-circuit voltage of cells. Table III presents the measured temperature behavior of field cells. Analys is of this behavior indicates that field cells behave like conventional cells which are made from much lower resistivity silicon than the field cells. Further confirmation of this analysis was obtained by determining the junction characteristics by measuring short-circuit current and open-circuit voltage at several illumination levels. Table IV shows the junction characteristics of $10 \Omega-\mathrm{cm}$ field effect cells to be very similar to those of cells made from much lower resistivity silicon and to differ appreciably from the characteristics of conventional structure $10 \Omega-\mathrm{cm}$ cells.

It was evident that the field at the back surface affected the $n^{+}-p$ barrier in a manner equivalent to that of increasing the majority carrier density of the p-type bulk. The mechanism postulated to create the effects discussed is presented in figure 3.

The aluminum diffused $\mathrm{p}^{+}$region at the cell back results in injection of holes into the back of the $p$ bulk, creating a high density of holes at this boundary of the bulk. The $\mathrm{n}^{+}$phosphorusdiffused region at the cell front constitutes a barrier to movement of holes to the front contact. Conversely, the $\mathrm{n}^{+}$region at the front of the bulk injects electrons into the bulk while the $\mathrm{p}^{+}$region at the back constitutes a barrier to movement of electrons to the back contact. The injection of a high concentration of majority carriers at the back of the bulk while not permitting them to leave freely at the front results in transfer of 
the majority carrier disturbance from the back to the front. There is, consequently, an increase in hole density at the front of the bulk $p$ region. This, in turn, raises the $n^{+}-p$ barrier height and gives the cell the characteristics of a cell made from lower resistivity silicon. It was expected, based upon the mechanisms outlined, that the opencircuit voltage of a field cell would show a dependency on minority carrier lifetime in the bulk because the hole concentrations at both the front and back of the bulk as well as the current flow within the bulk are functions of the bulk minority carrier lifetime. A dependency on cell thickness should also exist based upon the mechanism postulated.

The dependence of cell open-circuit voltage on minority carrier diffusion length in the bulk and cell thickness was investigated by irradiating both field effect and control cells of various thicknesses with selected fluences of $1-\mathrm{MeV}$ electrons. The variation of bulk minority carrier diffusion length with fluence in such irradiations, compiled from measurements made over many years on conventional cells, is shown in figure 4. Table V compares the open-circuit voltage of conventional $\left(n^{+}-p\right)$ cells and alloyed-through field cells after irradiation. The open-circuit voltages of the field cells show a marked dependence on cell thickness, with the thinner cells retaining their voltage superiority (compared to conventional cells) to greater fluences. The effect of back surface field on the open-circuit voltage apparent ly vanishes when the post-bombardment minority carrier diffusion length, $I_{B}$, decreases to values less than $0.4 \mathrm{~W}$, where $\mathrm{W}$ is the cell thickness. As long as $I_{B} \geq 0.7 \mathrm{~W}$ the open-circuit voltage of field cells is significantly higher than that of conventional cells.

The results obtained for some samples of field and control cells of different thicknesses bombarded to a dose of $3 \times 10^{14} \mathrm{l}-\mathrm{MeV}$ electrons are shown in Table VI. For this dose, only the 0.004 -inch-thick cells meet the criterion $L_{B} \geq$ $0.7 \mathrm{~W}$, and these cells have very little loss of current and have open-circuit voltages well above those of the other cells shown in Table VI.

Based upon the criteria that $L_{B} \geq 0.7 \mathrm{~W}$ and the values of $\mathrm{I}_{B}$ shown in figure 4 , it can be calculated that thicknesses of field cells, i.e., the distance from the front junction to the thin electric field region in the bulk, will have to be 0.004 inches or less, in order to retain advantages of back surface fields over the entire lifetime of most space missions. Small values of $W$ are attainable in physically rugged thick cell structures by the design and approach depicted in figure 5. The resistivity of the epitaxially deposited silicon layer shown in figure 5 should be in the 10-20 $\Omega-\mathrm{cm}$ range to avoid carrier removal damage (8).

\section{CONCLUSIONS}

Back surface field effect cells can be made by simplified processing using a new alloy-through back contact process. Cells so made have unusually high open-circuit voltage, vastly improved temperature behavior, and, if made with antireflection coatings, would have AMO efficiencies as high as 12 percent. Alloy-through processing should permit savings in labor, materials, and facilities necessary for field cell fabrication and should result in more reliable and adherent solar cell contacts.

Thin $10 \Omega-\mathrm{cm}$ alloy-through cells can be made with unusually high open-circuit voltages, shortcircuit currents, and fill factors. Avo efficiencies of 11 percent (based on assumed coating factors), the desirable temperature behavior of $2 \Omega-\mathrm{cm}$ cells, and increased radiation damage resistance were attained in 0.004-inch-thick alloyedthrough cell structures.

Several experiments performed indicate that the novel characteristics and behavior of alloyedthrough cells are caused solely by the presence of the electric field region at their back surfaces. A mechanism proposed for the behavior of alloyedthrough cells predicted that bulk minority carrier diffusion length and cell thickness play a vital role in the effectiveness of the back surface electric field. Results of irradiations of field cells corroborated the prediction. It is further predicted that creation of better quality $\mathrm{p}^{+} \mathrm{p}$ junctions at the cell back surface and preservation of higher minority carrier lifetimes in the $p$ region adjacent to the back contact after fabrication will lead to much better field cells than those reported upon to date.

\section{ACKNOWLEDGEMENT}

The contribution of $R$. Statler, who arranged for bombardment of cells at the Naval Research Laboratory, is gratefully acknowledged.

\section{REFERENCES}

1. Wolf, M.: Proceedings of the IEEE, 1963, p. 674.

2. Iles, P. A.: Conference Record of the Eighth IEEE Photovoltaic Specialists Conference, August 1970, p. 345.

3. Fisher, H.; and Pschunder, W.: Conference Record of the Eighth IEEE Photovoltaic Specialists Conference, August 1970, p. 70.

4. Wolf, M.: Research for the Improvement of Silicon Solar Cell Efficiency. Contract report, NASA Grant NGL 39-010-001, January 1971.

5. Lamneck, J. H.; Schwartz, L; and Spakowski, A. E.: A Reliable All Silver Front Contact for Silicon Solar Cells. Conference Record of the Ninth IEEE Photovoltaic Specialists Conference, May 1972. 
6. Imamura, M. S. and Portscheller, J. I.: Conference Record of the Eighth IEEE Photovoltaic Specialists Conference, August 1970, p. 102.

7. Mandelkorn, J.; McAfee, C.; Kesperis, J.; Schwartz, L.; and Pharo, W.: J. Electrochem. Soc., pp. 109, 313, 1962 .

8. Mandelkorn, J.; Schwartz, L.; Broder, J. D.; Kautz, H. E.; and Ulman, R.: J. Appl. Physics, 32, 2258, 1964 .

Table I

FABRICATION OF AI ALIOYED AND DIFFUSED FIELD EFFECT CELIS

\begin{tabular}{|c|c|c|}
\hline Process & Alloy-Through & Normal \\
\hline 1 Etch wafers & $\sqrt{ }$ & $\sqrt{ }$ \\
\hline 2 Diffuse phosphorus & $840^{\circ} \mathrm{C}, 30 \mathrm{~min}$. & $840^{\circ} \mathrm{C}, 30 \mathrm{~min}$ \\
\hline $\begin{array}{l}3 \text { Remove surface } \\
\text { oxides }\end{array}$ & $\sqrt{ }$ & $\checkmark$ \\
\hline $\begin{array}{l}4 \text { Mask front, etch } \\
\text { back }\end{array}$ & - & $\checkmark$ \\
\hline 5 Clean & - & $\sqrt{ }$ \\
\hline $\begin{array}{c}6 \text { Evaporate Al } \\
\text { on back }\end{array}$ & - & $\sqrt{ }$ \\
\hline 7 Heat & - & $800^{\circ} \mathrm{C}, 4 \mathrm{hrs}$. \\
\hline 8 Evaporate contacts & $\sqrt{ }$ & $\checkmark$ \\
\hline 9 Heat & $800^{\circ} \mathrm{C}, 4 \mathrm{hrs}$ & $600^{\circ} \mathrm{C}, 5 \mathrm{~min}$. \\
\hline Lo Etch e & $\sqrt{ }$ & $\sqrt{ }$ \\
\hline
\end{tabular}

Table II

CHARACTERISTICS OF FIELD EFFECT AND CONTROL CELIS $10 \Omega-\mathrm{cm}$, bare

\begin{tabular}{|c|c|c|c|c|c|c|}
\hline $\begin{array}{l}\text { Thickness, } \\
\mathrm{V}_{\mathrm{oc}}{ }^{1} \text {, volts }\end{array}$ & $\begin{array}{l}\text { in. } \\
\text { Control } \\
\text { Field }\end{array}$ & $\begin{array}{l}0.50 \\
0.58\end{array}$ & $\begin{array}{l}.006 \\
0.525 \\
0.58\end{array}$ & $\begin{array}{r}.008 \\
0.535 \\
0.58\end{array}$ & $\begin{array}{l}.012 \\
0.55 \\
0.58\end{array}$ & $\begin{array}{c}.020 \\
0.555 \\
--\end{array}$ \\
\hline $\mathrm{I}_{\mathrm{sc}}{ }^{2}, \mathrm{ma}$ & $\begin{array}{l}\text { Control } \\
\text { Fleld }\end{array}$ & $\begin{array}{c}44 \\
50.5\end{array}$ & $\begin{array}{c}47 \\
51.5\end{array}$ & $\begin{array}{c}49 \\
52.5\end{array}$ & $\begin{array}{c}52.5 \\
53\end{array}$ & $\begin{array}{c}53.5 \\
--\end{array}$ \\
\hline F.F. ${ }^{3}, \not$ & $\begin{array}{l}\text { Control } \\
\text { Field }\end{array}$ & & & .75 & & \\
\hline Eff. ${ }^{4}, \phi$ & $\begin{array}{l}\text { Control } \\
\text { Field }\end{array}$ & $\begin{array}{r}8.25 \\
11.25\end{array}$ & $\begin{array}{c}9.25 \\
11.6\end{array}$ & $\begin{array}{l}10.3 \\
11.8\end{array}$ & $\begin{array}{l}11 \\
12\end{array}$ & 11.3 \\
\hline
\end{tabular}

$1 \mathrm{~V}_{\mathrm{oc}}$ measured at $25^{\circ} \mathrm{C}$ for $\mathrm{I}_{\mathrm{sc}}=65 \mathrm{ma}$.

$2 I_{\text {c }}$ as measured under xenon simulator and Lewis filter wheel simulator (NASA TND-2562, 1965).

3 Fill Factor at $25^{\circ} \mathrm{C}$ for $I_{s C}=65 \mathrm{ma}$.

4 Efficiency calculated for $136 \mathrm{mw} / \mathrm{cm}^{2}$ AMO equivalent illumination and if cells had antireflection coating with coating factor of 1.4 .
Table III

TEMPERATURE BEHAVIOR OF FIELD EFFECT AND CONTROI CELIS

\begin{tabular}{|c|c|c|c|c|c|c|}
\hline \multirow{3}{*}{$\stackrel{\rho}{\Omega-\mathrm{cm}}$} & \multirow{3}{*}{ Type } & \multirow{3}{*}{$\begin{array}{c}\text { Thick. } \\
\text { in. }\end{array}$} & $\mathrm{T}$, & ${ }^{\circ} \mathrm{C}$ & \multirow{3}{*}{$\begin{array}{c}\text { T. Coeff. } \\
\mathrm{mv} /{ }^{\circ} \mathrm{C}\end{array}$} & \multirow{3}{*}{$\begin{array}{c}\mathrm{F} \cdot \mathrm{F} . \\
\mathrm{T}=160^{\circ} \mathrm{C} \\
\%\end{array}$} \\
\hline & & & 60 & 160 & & \\
\hline & & & \multicolumn{2}{|c|}{$v_{o c}$, volts } & & \\
\hline \multirow{2}{*}{10} & $\begin{array}{l}\text { Control } \\
\text { Field }\end{array}$ & $\begin{array}{l}.006 \\
.006\end{array}$ & $\begin{array}{l}0.436 \\
0.482\end{array}$ & $\begin{array}{l}0.193 \\
0.267\end{array}$ & $\begin{array}{l}2.43 \\
2.15\end{array}$ & $\begin{array}{c}47 \\
54.5\end{array}$ \\
\hline & $\begin{array}{l}\text { Field } \\
\text { Control }\end{array}$ & $\begin{array}{l}.015 \\
.022\end{array}$ & $\begin{array}{l}0.481 \\
0.465\end{array}$ & $\begin{array}{l}0.264 \\
0.235\end{array}$ & $\begin{array}{l}2.17 \\
2.3\end{array}$ & $\begin{array}{c}50 \\
47.5\end{array}$ \\
\hline 1 & Control & .020 & 0.485 & 0.275 & 2.1 & 55 \\
\hline
\end{tabular}

Table IV

COMPARISON OF JUNCTION CHARACTERISTICS OF FIEID EFFECT AND CONTROL CELIS

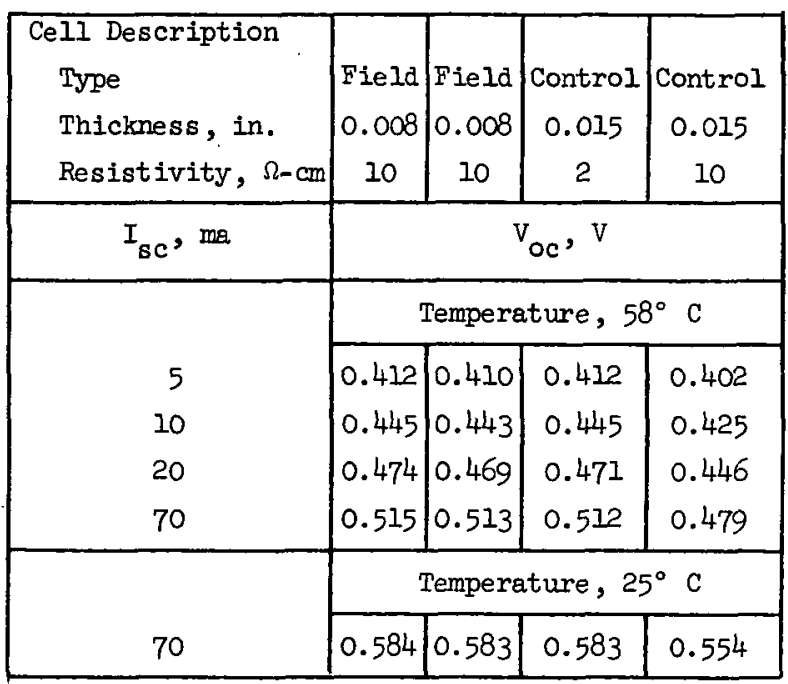

\section{Table V}

OFEN CIRCUIT VOLTAGE AS A FUNCTION OF THICKNESS AND BULK DIFFUSION IENGTH, I $10 \Omega \mathrm{cm}$ cells

\begin{tabular}{|c|c|c|c|c|}
\hline $\begin{array}{l}\text { I MeV Fluence, } \mathrm{e} / \mathrm{cm}^{2} \\
\text { Estimated } \mathrm{I}_{\mathrm{B}}, \mathrm{m} \\
\text { Thick Control Cells, } \\
\text { Voc, Volts }\end{array}$ & 0.555 & $\begin{array}{l}3 \times 10^{13} \\
125-140 \\
0.540\end{array}$ & $\begin{array}{c}9 \times 10^{13} \\
80-110 \\
0.535\end{array}$ & $\begin{array}{c}3 \times 10^{14} \\
60-75 \\
0.520\end{array}$ \\
\hline $\begin{array}{l}\text { Field Effect Cells } \\
\text { Thickness } \\
\text { in. }\end{array}$ & \multicolumn{4}{|c|}{$\mathrm{v}_{\text {oc }}$, Volts } \\
\hline $\begin{array}{ll}.015 & 375 \\
.012 & 300 \\
.008 & 200 \\
.006 & 150 \\
.0042 & 105\end{array}$ & $\begin{array}{l}0.573 \\
0.573 \\
0.576 \\
0.573 \\
0.572\end{array}$ & $\begin{array}{l}0.540 \\
0.560 \\
0.565 \\
0.565 \\
-.--\end{array}$ & $\begin{array}{l}0.535 \\
0.535 \\
0.547 \\
0.550 \\
-.--\end{array}$ & $\begin{array}{l}0.520 \\
0.520 \\
0.520 \\
0.526 \\
0.542\end{array}$ \\
\hline
\end{tabular}


Table VI

IRRADIATION RESULTS FOR FIELD EFFECT

AND CONTROL CELLS

FUUENCE: $3 \times 10^{14} 1-\mathrm{MeV}$ electrons $/ \mathrm{cm}^{2}$;

$10 \mathrm{ohm}-\mathrm{cm}$ bare cells; estimated

bulk diffusion length ${ }^{1}$ : 60-75 im

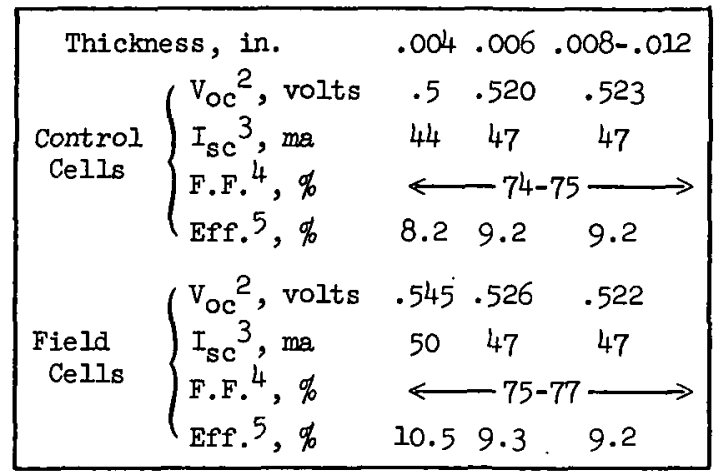

$1 I_{\mathrm{B}}$, post bombardment minority carrier diffusion length.

$2 \mathrm{~V}_{\mathrm{oc}}$ measured at $25^{\circ} \mathrm{C}$ for $\mathrm{I}_{\mathrm{sc}}=65 \mathrm{ma}$.

$3 I_{S C}$ as measured under xenon simulator and Lewis filter wheel simulator (NASA TND-2562, 1965).

4 Fill Factor at $25^{\circ} \mathrm{C}$ for $I_{s c}=65 \mathrm{ma}$.

5 Efficiency calculated for $136 \mathrm{mw} / \mathrm{cm}^{2}$ AMO equivalent illumination and if cells had antireflection coating with coating factor of 1.4 . 
STEPS IN FABRICATION OF ALLOYED-THROUGH CELLS

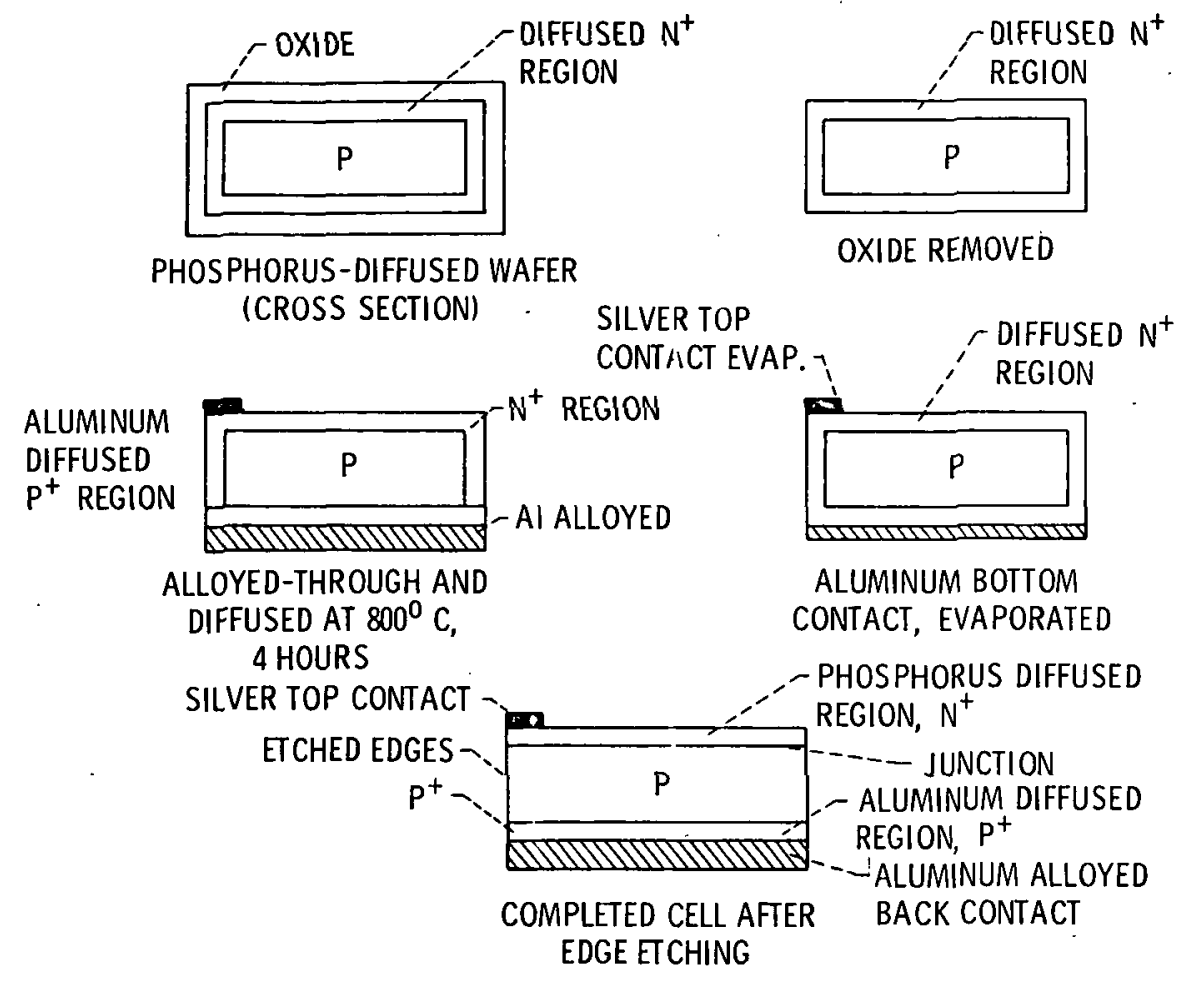

Fig. 1.

TYPES OF ALLOYED BACK CONTACT CONFIGURATIONS

TYPE 1, WINDOW CONTACT

NORMAL $V_{O C}$
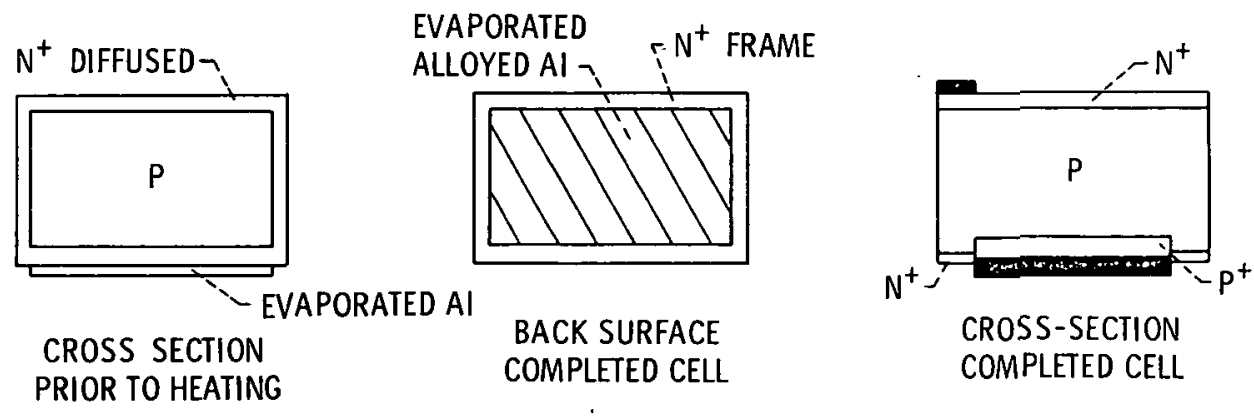

TYPE 2, ENTIRE BACK CONTACTED

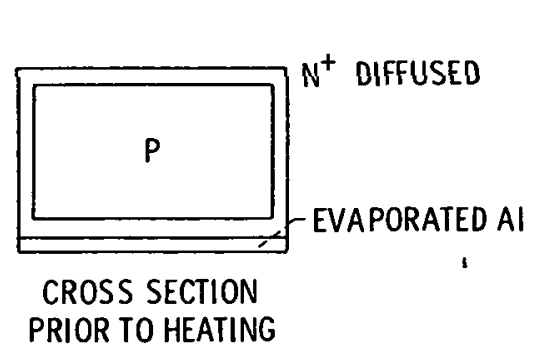

$\mathrm{HIGH} \mathrm{VOC}$

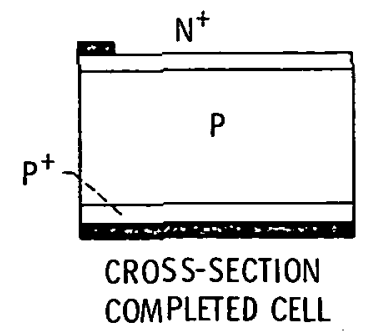

Fig. 2. 


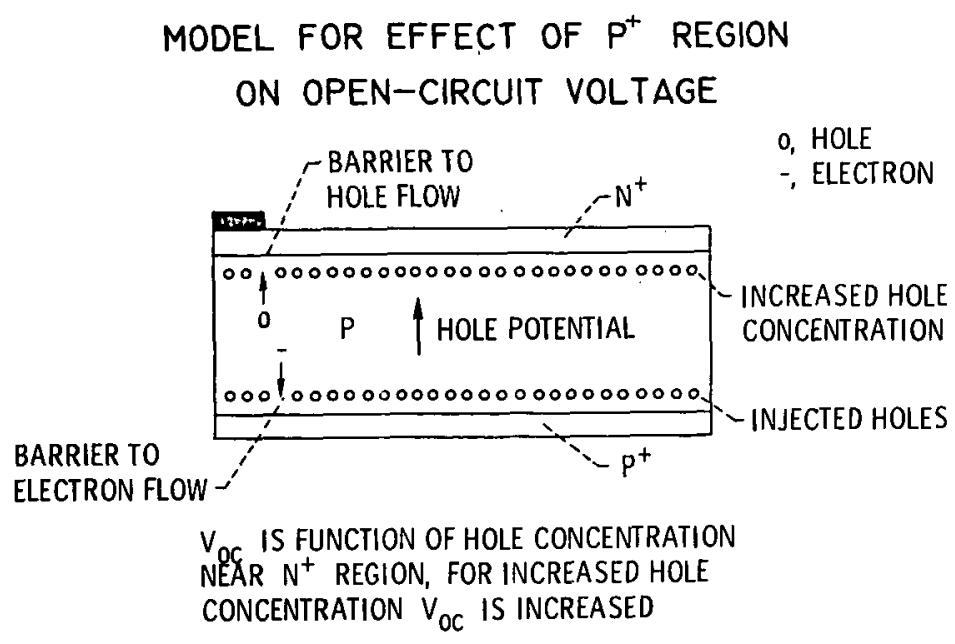

Fig. 3.

\section{MINORITY CARRIER DIFFUSION LENGTHS}

PRESERVED IN BOMBARDED 10 OIMM-CM CELLS

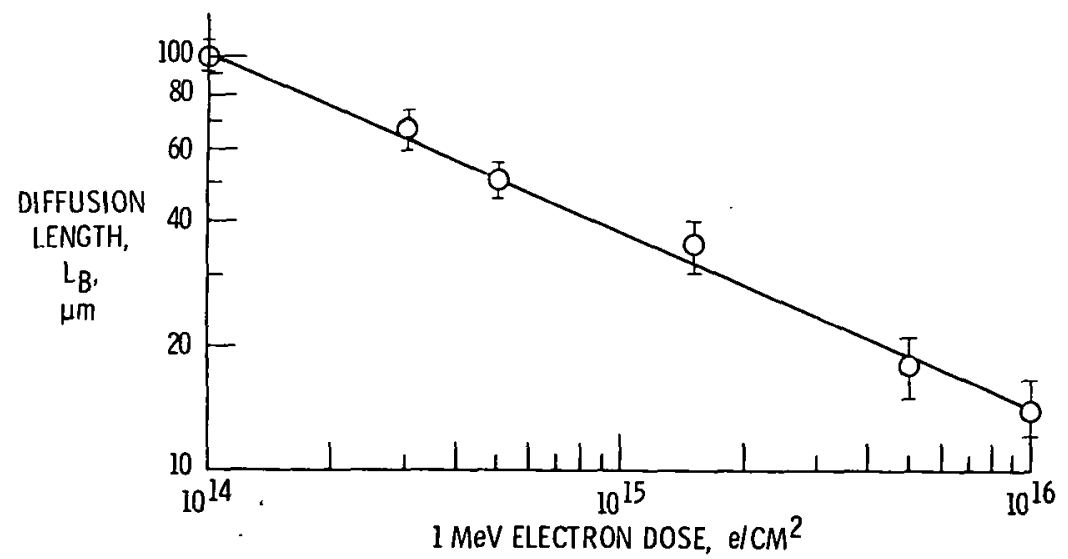

Fig. 4.

\section{RADIATION DAMAGE RESISTANT \\ BACK SURFACE FIELD CELL}

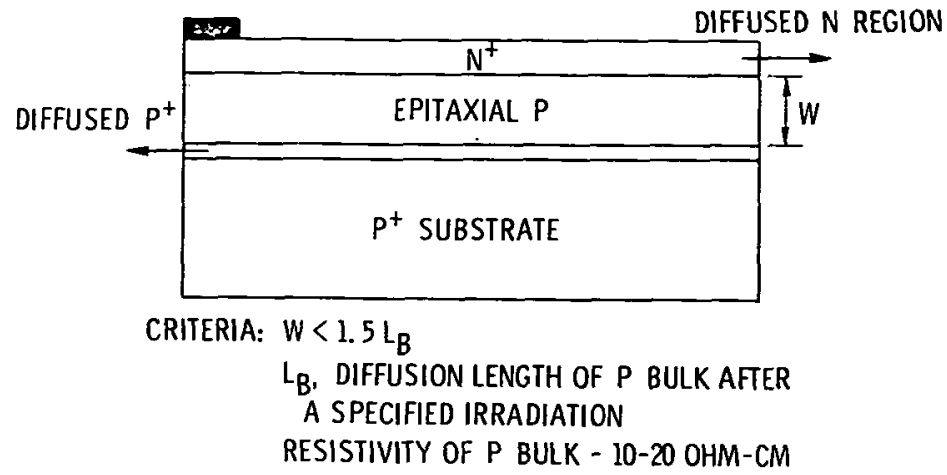

Fig. 5. 